\title{
KEMAMPUAN REPRESENTASI MATEMATIS MAHASISWA DALAM MENYELESAIKAN MASALAH STATISTIKA BERDASARKANLANGKAH KRULIK DAN RUDNICK
}

\author{
An Nur Ami Widodo ${ }^{1)}$, Dedi Nur Aristiyo ${ }^{2)}$ \\ ${ }^{12)}$ Program Studi Pendidikan Matematika, FKIP, Universitas Peradaban, Indonesia
}

amiaqeela@gmail.com; dedinuraristiyo@gmail.com

\begin{abstract}
This research intended to describe the mathematical representation of students in solving statistical problems based on the Krulik anf Rdunick steps. This research is a qualitative descriptive study. The subjects of this study were students of the second semester mathematic education study program. The procedure of subjects using purposive sampling techniques. Data collection techniques in this study were observation, interviews and documentation. Data validity used triangulation. Data analysis techniques using the Mile and Huberman step, namely data reduction, data presentations, drawing conclusions and verifyingconclusions. The results The results of this study are as follows: (1) subjects with high ability in the read and think and exploration and plan stages, using verbal and symbolic representations. The stage of select a strategy, using symbolic representation. The find and answer stage, uses symbolic and visual representations. In the reflect and extend step, the subject uses verbal representations. For students with moderate ability in the stage of read and think and explore and plan using verbal representation. The stage of finding an answer and select a strategy using verbal and symbolic representation. The reflect and extend stage of the subject uses symbolic representations. In students with low ability to read and think and explore and plan using verbal representation. Stage select a strategy subject using symbolic representation.
\end{abstract}

Keywords : Mathematical representation, mathematical problem solving, Krulik and Rudnick steps

ABSTRAK
Penelitian ini bertujuan untuk mengetahui representasi matematis mahasiswa dalam
menyelesaikan masalah statistika berdasarkan langkah Krulik dan Rudnick.Penelitian
ini adalah penelitian deskriptif kualitatif. Subjek penelitian ini adalah mahasiswa
progam studi pendidikan matematika semester II. Pengambilan subjek menggunakan
teknik purposive sampling.Teknik pengumpulan data dalam penelitian ini adalah
observasi, wawancara, dan dokumentasi.Validitas data menggunakan triangulasi.
Teknik analisis data menggunakan model Miles and Huberman yaitu reduksi data,
penyajian data, menarik kesimpulan, dan memverifikasi kesimpulan. Hasil penelitian ini
adalah sebagai berikut : (1) subjek dengan kemampuan tinggi tahap read and
thinksertaexplore and plan, menggunakan representasi verbal dan simbolik. Tahap select
a strategy, menggunakan represesentasi simbolik. Tahap find an answer, menggunakan
representasi simbolik dan representasi visual. Pada langkah reflect and extend, subjek
menggunakan representasi verbal. Pada mahasiswa dengan kemampuan sedang pada


tahap read and think serta explore and planmenggunakan representasi verbal.Tahap find an answer serta select a strategy menggunakan representasi verbal dan simbolik. Tahap reflect and extend subjek menggunakan representasi simbolik. Pada mahasiswa dengan kemampuan rendah pada read and think serta explore and plan menggunakan representasi verbal. Tahap select a strategy subjek menggunakan representasi simbolik.

Kata Kunci : Representasi matematis, pemecahan masalah matematis, langkah Krulik dan Rudnick.

\section{PENDAHULUAN}

Matematika merupakan sarana berpikir logis untuk memecahkan masalah dalam kehidupan sehari-hari. National Council of Teachers of Mathematics $\quad 2000$ menyatakan bahwa dalam pelaksanaan pembelajaran matematika di sekolah, guru harus memperhatikan lima kemampuan matematis, yaitu: kemampuan pemecahan masalah, penalaran, komunikasi, koneksi, dan representasi. Sabirin (2014) menyatakan bahwa representasi adalah bentuk interpretasi pemikiran siswa terhadap suatu masalah, yang digunakan sebagai alat bantu untuk menemukan solusi dari masalah tersebut. Bentuk interpretasi siswa dapat berupa kata-kata atau verbal, tulisan, gambar, tabel, grafik, benda konkrit, simbol matematika dan lain-lain.Kemampuan representasi matematis dapat diartikan sebagai kemampuan seseorang merubah permasalahan kedalam bentuk gambar, grafik, tabel, diagram, persamaan atau tulisan dan memecahkannya untuk mengembangkan kemampuan yang dimiliki.

Masalah dalam materi statistika aplikasinya dapat berupa soal pemecahan masalah, sehingga memerlukan kemampuan representasi yang baik dalam menyelesaikan persoalan yang diberikan. Permasalahan matematika dapat dipecahakn melalui beberapa proses langkah, Krulik dan Rudnick (1995) menguraikan mengenai proses yang harus dilakukan dalam pemecahan masalah, yaitu: (1) Membaca dan Berpikir (Read and Think), (2) mengeksplor dan merencanakan penyelesaian (Explore and Plan),(3) memilih strategi untuk menyelesaikan masalah (Select a Strategy), (4) mengkomputasi untuk menemukan jawaban (Find an Answer), dan (5) memikirkan kasus lain dan memperluas (Reflect and Extend).

Kemampuan pemecahan masalah statistika merupakan aspek penting, akan tetapi kebanyakan kemampuan mahasiswa dalam hal tersebut masih rendah. Berdasarkan hasil wawancara dengan dosen pengampu menyatakan bahwa hasil UTS dari 19 mahasiswa pendidikan matematika semester IV tahun ajaran 2018/2019 hanya $42.19 \%$ yang mencapai nilai $\geq 75$. Hal ini juga ditunjukkan pada jawaban mahasiswa sebagai berikut: 


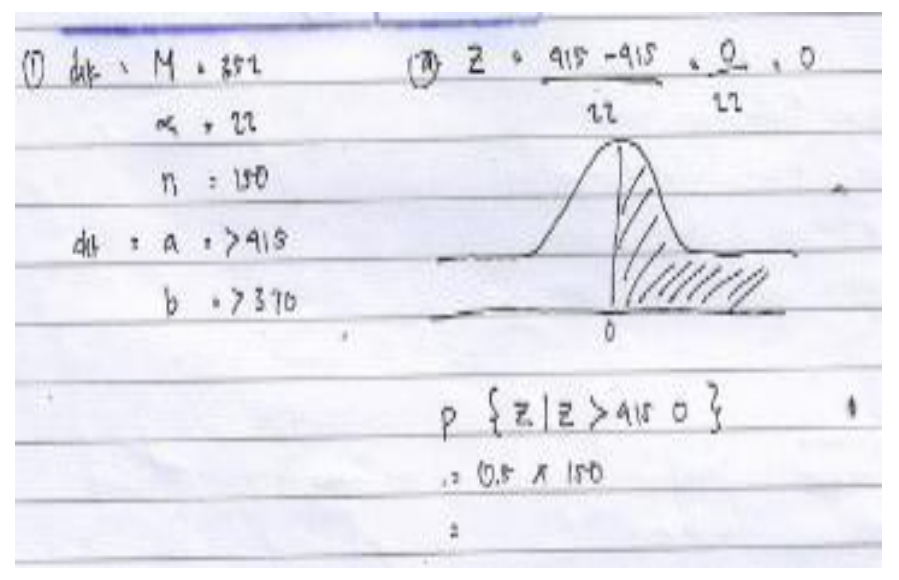

Gambar 1.Jawaban UAS Statistik

Berdasarkan dari jawaban soal pada Gambar 1, terlihat bahwa mahasiswa pada langkah Read and Think serta Explore and Plan, mahasiswa menyampaikan hal yang diketahui tetapi tidak menuliskan apa yang seharusnya ditanyakan, pada langkah Select a strategy dan find an answer, mahasiswa tidak menuliskan rumus yang akan digunakan langsung melakukan komputasi. Mahasiswa menggunakan representasi grafik kurva normal akan tetapi salah dalam menentukan konfigurasi daerah kritisnya, sehingga menyebabkan kesalahan pada langkah reflect and extend. Hal ini berarti representasi matematis dalam menyelesaikan masalah berdasarkan langkah Krulik dan Rudnick mahasiswa masih rendah.

Dalam menyelesaikan suatu masalah matematika mahasiswa memiliki cara yang berbeda-beda. Setiap orang memiliki cara dan kemampuan tersendiri dalam bertindak, yang dinyatakan melalui aktivitas perseptual dan intelektual secara konsisten. Aspek perseptual dan intelektual mengungkapkan bahwa setiap individu memiliki ciri khas dan karakter yang berbeda dengan individu lain. Azizah (2015: 10) mengatakan bahwa kemampuan matematika siswa dalam memecahkan masalah adalah kesanggupan atau kecakapan seorang siswa dalam menguasai suatu keahlian dan digunakan untuk mengerjakan atau memecahkan berbagai macam permasalahan dalam permasalahan matematika.

Karakteristik dasar yang berbeda sangat cocok untuk diterapkan dalam penelitian yang melibatkan kemampuan representasi matematis mahasiswa dalam menyelesaikan masalah statistika. Karena permasalahan statistika terutama materi Uji Hipotesis memiliki ragam representasi penyelesaian dalam memecahkan masalah berdasarkan langkah Krulik dan Rudnick, dimana setiap mahasiswa memiliki gaya berpikir yang berbeda dalam menyelesaikan soal tersebut, seperti hal nya mahasiswa dengan kemampuan tinggi, sedang dan rendah.

Berdasarkan

penelitian

Yudhanegara dan Lestari (2017), hasil analisis data dapat disimpulkan bahwa terdapat perbedaan kemampuan representasi matematis mahasiswa pada 
matakuliah system geometri berdasarkan latar belakang prestasi belajar mata kuliah geometri transformasi. Kelompok yang memiliki perbedaan kemampuan representasi matematis kelompok Amat Baik lebih unggul dari kelompok Baik, Cukup, dan Kurang.

Dari uraian di atas, peneliti tertarik untuk melakukan penelitian dengan judul "Kemampuan Representasi Matematis Mahasiswa dalam Menyelesaikan Masalah Statistika berdasarkan langkah Krulik dan Rudnick".

Berdasarkan latar belakang masalah, maka dapat dirumuskan permasalahan bagaimana kemampuan representasi matematis mahasiswa dalam menyelesaikan masalah Statistika berdasarkan langkah Krulik dan Rudnick?

Tujuan dalam penelitian ini adalah untuk mengetahui representasi matematis dalam menyelesaikan masalah Statistika berdasarkan langkah Krulik dan Rudnik.

Lingkup permasalahan penelitian ini mahasiswa dibagi menjadi tiga kelompok kemampuan yaitu tinggi, sedang dan rendah.

\section{LANDASAN/KAJIAN TEORI Representasi Matematis}

Representasi matematis merupakan salah satu kompetensi yang harus dimiliki oleh mahasiswa. Menurut Goldin (2002) representasi adalah suatu bentuk atau susunan yang dapat menggambarkan, mewakili, atau melambangkan seseuatu dalam suatu cara. Downs dan Downs (Mudzakir,
2006) menyebutkan bahwa representasi merupakan konstruksi matematik yang dapat menggambarkan aspek-aspek konstruksi matematik yang lainnya. Dua buah konstruksi matematik dalam hal ini, harus saling berkaitan satu sama lain, bahkan konstruksi yang satu mempunyai peran yang penting untuk konstruksi yang lainnya. Selanjutnya Hwang et.al (2007) dalam psikologi matematika, representasi bermakna deskripsi hubungan antara objek dengan simbol.

Representasi berkaitan erat dengan konsep matematika. Pada kasuskasus tertentu, seperti grafik dengan fungsi yang sulit untuk dipahami dan memperoleh konsep tanpa menggunakan representasi tertentu. Representasi yang berbeda namun mengacu pada konsep yang sama akan saling melengkapi dan saling berkontribusi untuk pemahaman secara global dari konsep tersebut (Gagatis dan Ella, 2005). Berdasarkan pernyataan tersebut terdapat tiga anggapan untuk penguasaaan konsep dalam matematika yaitu pertama, kemampuan untuk mengidentifikasi konsep dalam beragam representasi.Kedua, kemampuan menangani secara fleksibel konsep dalam sistem-sistem representasi tertentu. Ketiga, kemampuan untuk menerjemahkan konsep dari sistem representasi ke sistem representasi lainnya.

Representasi yang digunakan kemudian dimunculkan oleh mahasiswa merupakan ungkapan-ungkapan dari gagasan-gagasan atau ide matematika yang ditampilkan mahasiswa dalam upayanya untuk mencari suatu solusi 
dari masalah yang sedang dihadapinya. Standar representasi yang ditetapkan oleh NCTM (2000) harus memungkinkan mahasiswa untuk:

a. Mencipta dan menggunakan representasi untuk mengorganisasi, mencatat, dan mengkomunikasikan ide-ide matematika

b. Memilih, menerapkan dan menerjemahkan representasi matematika untuk memecahkan masalah

c. Menggunakan representasi untuk memodelkan dan menginterpretasikan fenomena fisik sosial dan fenomena matematika.

Representasi seperti bentuk gambar, kata-kata (verbal), tabel, ebnda konkrit atau simbol. Selain itu, representasi juga membantu mahasiswa dalam mengkomunikasikan ide-ide mereka ketika dihadapkan suatu permasalahan.

\section{Pemecahan masalah Matematika Berdasarsarkan langkah Krulik dan Rudnick}

Pemecahan masalah matematika dipandang sebagai proses dan tujuan dari pembelajaran matematika, sebagai proses sebagai teknik dan pendekatan sedangkan sebagai tujuan berarti sebagai kemampuan kognitif yang dicapai setelah proses pembelajaran. Menurut Krulik dan Rudnick (1995) terdapat beberapa langkah dalam menyelesaikan masalah matematika yaitu: (1) Membaca dan Berpikir (Readand Think), (2) mengeksplor dan merencanakan penyelesaian (Explore and Plan), (3) memilih strategi untukmenyelesaikan masalah (Select a
Strategy), (4) mengkomputasi untuk menemukan jawaban (Find an Answer), dan (5) memikirkan kasus lain danmemperluas (Reflect and Extend). Krulik dan Rudnick (1995) menyatakan pemecahan masalah merupakan suatu proses. Dituliskan bahwa problem solving is the means by which an individualuses previously acquired knowledge, skill, and understanding to satisfy thedemands of an unfamiliar situation, yang berarti bahwa penyelesaian masalah merupakan sarana dimana seorang individu menggunakan pengetahuan, keterampilan, dan pemahaman yang telah diperoleh sebelumnya untuk memenuhi tuntutan situasi yang tak biasa. Penyelesaian masalah dapat dan harus dipelajari. Proses dari pemecahan masalah tersebut dapat dianalisis dan diwakili oleh beberapa tahapan. Berikut ini ialah tahapan pemecahan masalah yang dikemukakan oleh Krulik dan Rudnick (1995) yang mencakup aktivitas mental dan fisik yang digunakan seseorang untuk memecahkan masalah.

Tahapan pemecahan masalah menurut Krulick dan Rudnick sebagai berikut :

a. Read and Think (Membaca dan Berpikir)

Pada tahapan ini, setelah masalah ditemukan maka masalah tersebut harus dianalisis.Siswa harus memeriksa dan menaksir, menentukan pertanyaan dari masalah tersebut, keadaan yang tersaji kemudian harus divisualisasikan, dideskripsikan, dan dipahami.Masalah tersebut harus dapat 
diubah ke dalam bahasa yang biasa digunakan oleh siswa sendiri.

b. Explore and Plan (Menyelidiki dan Merencanakan)

Tahapan ini menunjukkan
bahwa siswa menganalisis dan
menetukan informasi yang cukup untuk
memecahkan masalah.Pengecoh atau
kalimat yang berlebih dapat
dihilangkan, data yang ada diatur dalam
bentuk tabel, gambar, sebuah model,
dan sebagainya. Perencanaan lebih
dikembangkan pada tahap ini.

\section{c. Select a Strategy (Memilih Strategi)}

Tahap yang ketiga ini menurut beberapa orang merupakan tahapan yang paling sulit. Strategi merupakan bagian dari proses pemecahan masalah yang dapat memberikan arah dan tujuan dalam memecahkan masalah tersebut. Rencana yang dipilih dipengaruhi oleh dua tahap sebelumnya. Pertanyaan yang sulit pada proses pemecahan masalah ialah strategi apa yang paling tepat digunakan untuk memecahkan masalah yang dihadapi. Hal ini dapat diselesaikan dengan banyak latihan. Apabila siswa berhasil menyelesaikan masalah, mereka harus terus berlatih dalam seni memecahkan masalah. Sehingga mereka dapat terbiasa dan bahkan dapat menggunakan berbagai jenis strategi dalam memecahkan masalah.

\section{d. Find an Answer (Menemukan Jawaban)}

Pada tahapan ini, kemampuan matematis sangat dibutuhkan untuk mencari jawaban. Kemampuan matematis ini didukung oleh perkiraan yang tepat. Dapat pula dibantu oleh kalkulator atau alat bantu lain.

\section{e. Reflect and Extend (Memikirkan Perkara Lain dan Memperluas)}

Pada tahap terakhir ini, siswa harus mengecek dengan tepat apakah kondisi awal dari masalah telah digabungkan, apakah pertanyaan sudah terjawab. Sebenarnya pada tahapan inilah proses berpikir kritis yang maksimal sangat dibutuhkan. Selain itu, alternatif jawaban pun harus ditemukan (bila ada) dan didiskusikan bersama. Permasalahan pun dapat diubah dengan memberi pertanyaan "bagaimana bila...".Jika memungkinkan, proses ini dapat diperluas untuk menemukan generalisasi atau konsep matematika yang mendasari situasi yang ada pada masalah.

\section{METODE PENELITIAN Jenis Penelitian}

Jenis penelitian yang dilakukan adalah penelitian deskriptif.Penelitian ini bertujuan untuk mendeskripsikan dan menghasilkan gambaran yang jelas dan terperinci mengenai reprsentasi matematis pemecahan masalah menurut langkah Krulik dan Rudnick mahasiswa.

\section{Waktu dan Tempat Penelitian}

Penelitian ini dilaksanakan di Universitas Peradaban Bumiayu, 
Kabupaten Brebes pada semester genap tahun pelajaran 2018/2019.Penelitian ini dilaksanakan selama 8 bulan, yaitu bulan Februari-September.

\section{Subjek Penelitian}

Subjek pada penelitian adalah mahasiswa matematika semester II. Selanjutnya dalam penelitian ini diambil 6 mahasiswa dengan kategori 2 kemampuan tinggi, 2 kemampuan sedang, dan 2 kemampuan rendah sebagai sumber data, penentuan subjek penelitian dilakukan dengan cara snowball sampling.

\section{Instrumen Penelitian}

Instumen dalam penelitian ini menggunakan tes untuk mengetahui representasi yang digunakan dan wawancara. Wawancara bertujuan agar peneliti dapat memperoleh informasi mengenai jenis representasi dalam pemecahan masalah berdasarkan langkah Krulik dan Rudnick (1995).Selanjutnya data dianalisis dan dilakukan validasi menggunakan triangulasi. Data hasil triangulasi yang sama merupakan data subjek yang valid.

\section{Teknik Analisis Data}

Analisis data dalam penelitian ini mengacu pada model Miles dan
Huberman (1992), yakni reduksi, penyajian atau display data, serta kesimpulan atau verifikasi. Ketiga tahap tersebut tidak dilakukan secara berurutan, akan tetapi disesuaikan dengan kondisi yang dihadapi peneliti. Ketiga tahap analisis tersebut dijabarkan menjadi langkah-langkah sebagai berikut. (1) Membuat transkrip data verbal dari hasil rekaman. (2) Menelaah seluruh data dari sumber yaitu hasil pekerjaan subjek dan hasil wawancara. (3) Melakukan reduksi data. (4) Menyusun satuan-satuan analisis data dan melakukan pengkodean. (5) Menganalisis representasi berdasarkan langkah Krulik dan Rudnick (6) Melakukan penafsiran data. (7) Melakukan triangulasi. (8) Menulis hasil penelitian

\section{HASIL DAN PEMBAHASSAN}

\section{Hasil Penelitian}

Pengambilan data tes kemampuan pemecahan masalah dilakukan tanggal 16 Juli 2019. Selanjutnya mahasiswa dikelompokkan menjadi tiga kategori yaitu tinggi, sedang dan rendah. Hasil penggolongan kemampuan mahasiswa dapat dilihat pada table berikut :

Tabel 1.Penggolongan Kemampuan Mahasiswa

\begin{tabular}{|c|r|r|r|r|r|r|l|}
\hline Subjek & Soal 1 & Soal 2 & Soal 3 & Soal 4 & Soal 5 & Nilai & Kategori \\
\hline A1 & 12 & 15 & 12 & 15 & 14 & 68 & Sedang \\
\hline A2 & 18 & 15 & 20 & 18 & 15 & 86 & Tinggi \\
\hline A3 & 8 & 10 & 15 & 8 & 10 & 51 & Rendah \\
\hline A4 & 15 & 12 & 15 & 13 & 13 & 68 & Sedang \\
\hline A5 & 10 & 15 & 12 & 16 & 12 & 65 & Sedang \\
\hline A6 & 15 & 15 & 12 & 15 & 15 & 72 & Sedang \\
\hline A7 & 18 & 20 & 18 & 15 & 18 & 89 & Tinggi \\
\hline A8 & 13 & 16 & 8 & 10 & 16 & 63 & Rendah \\
\hline A9 & 5 & 8 & 10 & 8 & 12 & 43 & Rendah \\
\hline A10 & 12 & 16 & 8 & 15 & 15 & 66 & Sedang \\
\hline
\end{tabular}




\begin{tabular}{|c|r|r|r|r|r|r|l|}
\hline Subjek & Soal 1 & Soal 2 & Soal 3 & Soal 4 & Soal 5 & Nilai & Kategori \\
\hline A11 & 16 & 14 & 12 & 10 & 18 & 70 & Sedang \\
\hline A12 & 20 & 18 & 15 & 15 & 15 & 83 & Tinggi \\
\hline A13 & 16 & 16 & 10 & 18 & 16 & 76 & Tinggi \\
\hline A14 & 8 & 10 & 8 & 0 & 15 & 41 & Rendah \\
\hline A15 & 16 & 10 & 15 & 14 & 18 & 73 & Tinggi \\
\hline A16 & 8 & 6 & 12 & 0 & 15 & 41 & Rendah \\
\hline A17 & 18 & 15 & 15 & 15 & 15 & 78 & Tinggi \\
\hline A18 & 12 & 8 & 8 & 10 & 10 & 48 & Rendah \\
\hline A19 & 15 & 15 & 15 & 16 & 12 & 73 & Tinggi \\
\hline
\end{tabular}

Setelah subjek selesai mengerjakan tes tertulis, peneliti melakukan wawancara, berdasarkan hasil pekerjaan tertulis dengan tujuan untuk mengetahui representasi pemecahan masalah berdasarkan langkah Krulik Rudnick dan mengonfirmasi data serta klarifikasi jawaban subjek. Selanjutnya pada tahap akhir penelitian ini dilakukan triangulasi data, berikut triangulasi data pada setiap kategori.

Tabel 2 Triangulasi Hasil Analisis soal nomor 1 Subjek A.2 (kemampuan tinggi)

\begin{tabular}{|c|c|c|}
\hline $\begin{array}{l}\text { Langkah } \\
\text { Krulik dan } \\
\text { Rudnick }\end{array}$ & Hasil Analisis Tes & Hasil Analisis wawancara \\
\hline Read and Think & $\begin{array}{l}\text { Subjek mampu mendeskripsikan } \\
\text { yang diketahui dan ditanyakan } \\
\text { dengan baik, serta dapat } \\
\text { menuliskannya dalam kertas } \\
\text { jawaban yang telah disediakan. }\end{array}$ & $\begin{array}{l}\text { Subjek antusias pada saat } \\
\text { diminta membaca soal yang } \\
\text { diberikan dengan tenang dan } \\
\text { lantang } \\
\text { - } \\
\text { Subjek dapat menyebutkan } \\
\text { hal-hal yang diketahui dan } \\
\text { ditanyakan dengan benar. }\end{array}$ \\
\hline $\begin{array}{l}\text { Explore and } \\
\text { Plan }\end{array}$ & $\begin{array}{l}\text { Subjek mampu mengorganisasi } \\
\text { informasi yang diperoleh dalam } \\
\text { soal, seperti untuk memaparkan } \\
\text { prosedur uji hipotesis dengan } \\
\text { runtut dan merumuskan } \mathrm{H}_{0} \text { dan } \mathrm{H}_{1} \\
\text { serta daerah kritis sesuai dengan } \\
\text { hipotesisnya dengan benar }\end{array}$ & $\begin{array}{l}\text { Subjek dengan lantang } \\
\text { menjelaskan prosedur uji } \\
\text { hipotesis dengan tepat }\end{array}$ \\
\hline $\begin{array}{l}\text { Select } \\
\text { Strategy }\end{array}$ & $\begin{array}{l}\text { Subjek menuliskan apa yang telah } \\
\text { direncanakan, yaitu menuliskan } \\
\text { statistik uji untuk menguji } \\
\text { hipotesis yang akan digunakan } \\
\text { dalam } \\
\text { permasalahan, menyelesaikan } \\
\text { menggunakan statistic uji Z }\end{array}$ & $\begin{array}{l}\text { Subjek dapat menjawab } \\
\text { pertanyaan dengan tepat }\end{array}$ \\
\hline Find an Answer & $\begin{array}{l}\text { Subjek mengkomputasi masalah } \\
\text { yang telah dituliskan } \\
\text { menggunakan strategi yang telah } \\
\text { ditentukan }\end{array}$ & $\begin{array}{l}\text { Subjek menjelaskan komputasi } \\
\text { hasil yang diperoleh dan } \\
\text { membandingan dengan daerah } \\
\text { kritis }\end{array}$ \\
\hline
\end{tabular}




\begin{tabular}{|l|l|l|}
\hline $\begin{array}{c}\text { Langkah } \\
\text { Krulik dan } \\
\text { Rudnick }\end{array}$ & \multicolumn{1}{|c|}{ Hasil Analisis Tes } & Hasil Analisis wawancara \\
\hline $\begin{array}{l}\text { Reflect and } \\
\text { Extend }\end{array}$ & $\begin{array}{l}\text { Subjek memeriksa kembali } \\
\text { jawaban dan menyimpulkan } \\
\text { berdasarkan keputusan uji yang } \\
\text { diperoleh dengan bahasa sehari- } \\
\text { hari (bukan dalam terminology } \\
\text { statistic) }\end{array}$ & $\begin{array}{l}\text { Subjek } \\
\text { kesimpulan dari hasil yang } \\
\text { diperoleh }\end{array}$ \\
\hline
\end{tabular}

Tabel 3. Triangulasi Hasil Analisis soal nomor 1 Subjek A.10 (kemampuan sedang)

\begin{tabular}{|c|c|c|}
\hline $\begin{array}{l}\text { Langkah } \\
\text { Krulik dan } \\
\text { Rudnick }\end{array}$ & Hasil Analisis Tes & Hasil Analisis wawancara \\
\hline Read and Think & $\begin{array}{l}\text { Subjek mampu mendeskripsikan } \\
\text { yang diketahui dan ditanyakan } \\
\text { dengan baik, serta dapat } \\
\text { menuliskannya dalam kertas } \\
\text { jawaban yang telah disediakan } \\
\text { akan tetapi banyak coretan, hal ini } \\
\text { dikarenakan subjek tidak percaya } \\
\text { diri dengan apa yang telah } \\
\text { dituliskan. }\end{array}$ & $\begin{array}{l}\text { Subjek terlihat gugup dan } \\
\text { tegang saat membacakan } \\
\text { masalah dengan suara yang } \\
\text { pelan. Hal ini dimungkinkan } \\
\text { subjek sangat berhati-hati } \\
\text { dalam mengerjakan soal. }\end{array}$ \\
\hline $\begin{array}{l}\text { Explore and } \\
\text { Plan }\end{array}$ & $\begin{array}{l}\text { Subjek mampu mengorganisasi } \\
\text { informasi yang diperoleh dalam } \\
\text { soal. }\end{array}$ & $\begin{array}{l}\text { subjek diam sejenak untuk } \\
\text { memahami dan mencermati } \\
\text { soal dengan fokus masalah } \\
\text { yang terdapat dalam soal dan } \\
\text { merencanakan ide dengan } \\
\text { dengan menuliskan langkah- } \\
\text { langkah penyelesaian sesuai } \\
\text { prosedur uji hipotesis. }\end{array}$ \\
\hline $\begin{array}{l}\text { Select } \quad \text { and } \\
\text { Strategy }\end{array}$ & $\begin{array}{l}\text { subjek menuliskan ide dalam } \\
\text { pikirannya dengan cara } \\
\text { menuliskannya dalam persamaan- } \\
\text { persamaan tanpa menuliskan } \\
\text { rumus yang akan digunakan. }\end{array}$ & $\begin{array}{l}\text { Subjek menjelaskan rumus } \\
\text { yang akan digunakan. Subjek } \\
\text { lupa menuliskan rumusnya } \\
\text { dalam lembar jawab }\end{array}$ \\
\hline Find an Answer & $\begin{array}{l}\text { subjek melakukan komputasi } \\
\text { untuk memperoleh jawaban } \\
\text { dengan memasukkan satu persatu } \\
\text { persamaan ke dalam persamaan } \\
\text { yang lain sehingga diperoleh } \\
\text { jawaban yang benar. }\end{array}$ & $\begin{array}{l}\text { Subjek menjelaskan hasil yang } \\
\text { diperoleh. }\end{array}$ \\
\hline $\begin{array}{l}\text { Reflect } \\
\text { Extend }\end{array}$ & $\begin{array}{l}\text { subjek mencoba membandingkan } \\
\text { Zhitung dengan } Z_{\text {tabel }} \text { sesuai dengan } \\
\text { daerah kritis yang telah ditetapkan } \\
\text { akan tetapi keliru dalam } \\
\text { memberikan kesimpulan dalam } \\
\text { menentukan keputusan uji }\end{array}$ & $\begin{array}{l}\text { Subjek menjelaskan } \\
\text { kesimpulan dari hasil yang } \\
\text { diperoleh akan tetapi keliru }\end{array}$ \\
\hline
\end{tabular}




\begin{tabular}{|l|llll|l|}
\hline & $\begin{array}{l}\text { mengenai } \\
\text { diterima. }\end{array}$ & $\mathrm{H}_{0}$ & ditolak atau $\mathrm{H}_{0}$ & \\
\hline
\end{tabular}

Tabel 4 Triangulasi Hasil Analisis soal nomor 1 Subjek A.9 (kemampuan rendah)

\begin{tabular}{|c|c|c|}
\hline $\begin{array}{l}\text { Langkah } \\
\text { Krulik dan } \\
\text { Rudnick }\end{array}$ & Hasil Analisis Tes & Hasil Analisis wawancara \\
\hline Read and Think & $\begin{array}{lrr}\text { Subjek } & \text { tidak } & \text { menuliskan } \\
\text { informasi } & \text { secara } & \text { lengkap yang } \\
\text { terdapat pada soal } & \end{array}$ & $\begin{array}{l}\text { subjek membaca dengan suara } \\
\text { lantang dan jelas saat diberikan } \\
\text { masalah dan mampu } \\
\text { mengungkapkan hal-hal yang } \\
\text { diketahui dan ditanyakan } \\
\text { dengan lengkap. }\end{array}$ \\
\hline $\begin{array}{l}\text { Explore and } \\
\text { Plan }\end{array}$ & $\begin{array}{l}\text { Subjek tidak menuliskan secara } \\
\text { detail langkah-langkah dalam } \\
\text { menyelesaikan permasalahan, } \\
\text { seperti tidak menuliskan atau } \\
\text { merumuskan } \mathrm{H}_{0} \text { dan } \mathrm{H}_{1}\end{array}$ & $\begin{array}{l}\text { subjek berusaha menjelaskan } \\
\text { dan mengingat langkah-langkah } \\
\text { prosedur uji hipotesis yang } \\
\text { digunakan } \\
\begin{array}{l}\text { menyelesaikannya } \\
\text { dalam }\end{array}\end{array}$ \\
\hline $\begin{array}{l}\text { Select } \\
\text { Strategy }\end{array}$ & $\begin{array}{l}\text { Subjek menuliskan rumus yang } \\
\text { akan digunakan dalam } \\
\text { menyelesaikan soal tersebut akan } \\
\text { tetapi tidak tepat }\end{array}$ & $\begin{array}{l}\text { Subjek mencoba mengingat } \\
\text { rumus yang akan digunakan, } \\
\text { tetapi subjek tidak menjelaskan. }\end{array}$ \\
\hline Find an Answer & $\begin{array}{l}\text { subjek melakukan komputasi, } \\
\text { tetapi salah. }\end{array}$ & $\begin{array}{l}\text { Subjek menjelaskan hasil yang } \\
\text { diperoleh. }\end{array}$ \\
\hline $\begin{array}{l}\text { Reflect and } \\
\text { Extend }\end{array}$ & $\begin{array}{lrr}\text { Subjek tidak } & \text { menuliskan } \\
\text { kesimpulan akhir } & \end{array}$ & $\begin{array}{l}\text { Subjek menjelaskan hasil akhir } \\
\text { komputasi }\end{array}$ \\
\hline
\end{tabular}

\section{Pembahasan}

Berdasarkan hasil penelitian menunjukkan bahwa setiap kemampuan memiliki kesalahan yang berbeda. Pada mahasiswa dengan kemampuan tinggi. pada langkah Read and Think menggunakan representasi verbal, langkah Explore and Plan, menggunakan representasi verbal dan simbolik dengan memisalkan informasi yang diketahui dengan menggunakan symbol A dan B (karena data independent), subjek dapat memaparkan prosedur uji hipotesis dengan runtut dan merumuskan $\mathrm{H}_{0}$ dan $\mathrm{H}_{1}$ serta daerah kritis sesuai dengan hipotesisnya dengan benar. Langkah Select a strategy, menggunakan represesentasi simbolik, langkah Find a answer menggunakan representasi simbolik dan representasi visual, subjek dapat 
melakukan komputasi dengan benar dan dalam menentukan nilai kritis dan daerah kritis berdasarkan tingkat signifikasi, selain itu subjek menggambarkan kurva normal agar lebih mudah dalam menentukan keputusan uji mengenai $\mathrm{H}_{0}$. Pada langkah Reflect and extend menggunakan representasi verbal.

bahwa representasi matematis
mahasiswa dengan dengan kemampuan tinggi suka bereksperimen dalam menyelesaikan permasalahan dengan gambar dan simbol yang dibuat untuk menemukan solusi penyelesaian yang baru sesuai cara berpikirnya sendiri serta tidak terikat pada model matematis yang diajarkan oleh dosen. Sehingga dapat menemukan model penyelesaian lainnya sesuai dengan pengalaman belajar baru yang di coba sendiri dan dapat mengungkapkan solusi penyelesaiannya dengan ekspresi katakata tertulis yang logis. Hal ini sesuai dengan teori Witkin et al. (Rifqiyana, 2015) yang menyatakan bahwa, individu Field Independent (FI) cenderung analitik dan suka bereksperimen sendiri sesuai dengan pemikirannya. Sehingga dapat melakukan visualisasi dengan gambar dan melakukan model matematis selain dari yang sudah diajarkan oleh guru. Pernyataan tersebut selaras bahwa dalam penelitian ini subjek dengan kemampuan tinggi cenderung memiliki kategori Field Independent. Tidak berbeda dengan penelitian Rezki (2018) menyatakan bahwa untuk subjek berkemampuan tinggi memiliki kecenderungan penggunaan berbagai representasi matematis pada setiap tahapan pemecahan masalah seperti representasi verbal, simbolik dan visual sehingga mampu menyelesaikan masalah dengan baik dan benar.

Berbeda dengan representasi yang digunakan pada subjek dengan kemampuan sedang pada langkah read and think serta explore and plan menggunakan representasi verbal, pada lembar jawab banyak coretan hal ini dikarenakan subjek tidak percaya diri dengan apa yang telah dituliskan. Pada saat wawancara subjek terlihat gugup dan tegang saat membacakan masalah dengan suara yang pelan. Hal ini dikarenakan subjek sangat berhati-hati dalam mengerjakan soal. Langkah select a strategy serta find a answer menggunakan representasi simbolik. Langkah reflect and extend subjek menggunakan representasi simbolik, subjek mencoba membandingkan $Z_{\text {hitung }}$ dengan $\mathrm{z}_{\text {tabel }}$ sesuai dengan daerah kritis yang telah ditetapkan akan tetapi keliru dalam memberikan kesimpulan dalam menentukan keputusan uji mengenai $\mathrm{H}_{0}$ ditolak atau $\mathrm{H}_{0}$ diterima. Berdasarkan hasil analisis representasi matematis mahasiswa dengan dengan kemampuan sedang sangat berhati-hati dalam menyelesaikan permasalahan dengan representasi simbol yang dibuat untuk menemukan solusi penyelesaian serta lebih terikat pada model matematis yang diajarkan oleh dosen. Walaupun subjek menggunakan bentuk representasi verbal dan simbolik, tidak menjamin kebenaran jawaban apalagi jika pemilihan representasi yang kurang tepat atau tidak sesuai dengan masalah. Oleh karena itu, representasi matematis 
haruslah bervariasi (multiple representation) dan menggunakan polapola yang tepat sesuai dengan masalah seperti yang diungkapkan oleh Hwang, Chen, Dung, dan Yang (2007), bahwa ketika menyelesaikan masalah aplikasi matematika, siswa perlu mengamati dan menemukan pola-pola khusus yang ada di dalam masalah tersebut.

$$
\text { Berbeda pada mahasiswa }
$$

dengan kemampuan rendah pada langkah read and think serta explore and plan menggunakan representasi verbal, subjek membaca dengan suara lantang dan jelas saat diberikan masalah dan mampu mengungkapkan hal-hal yang diketahui dan ditanyakan dengan lengkap, namun tidak menuliskannya dalam lembar jawaban. Pada langkah select a strategy serta find $a$ answer subjek menggunakan representasi simbolik, subjek mengalami kesalahan pada penulisan rumus dan komputasi sehingga salah pada proses selanjutnya. Berdasarkan hasil analisis di atas bahwa representasi matematis mahasiswa dengan kemampuan rendah suka berpikir sederhana dalam menyelesaikan permasalahan tanpa memperhatikan simbol dan selalu menggunakan model matematis dengan pengalaman yang sudah diperoleh dari pembelajaran yang sudah diberikan dan kurang bisa mengungangkapkan solusi penyelesaian dengan kata-kata yang logis.

Hal ini sesuai dengan penelitian Rezki dkk (2018) bahwa kategori siswa berkemampuan rendah, kurang memiliki kemampuan penggunaan berbagai representasi matematis dalam pemecahan masalah pada tiap tahapan pemecahan masalahnya seperti representasi visual. Hal lain yang ditemukan adalah kurang terliti dalam melaksanakan rencana untuk menyelesaikan masalah. Perhitungan yang kurang teliti menyebabkan hasil tidak tepat.

\section{SIMPULAN DAN SARAN Simpulan}

Berdasarkan hasil analisis dapat disimpulkan bahwa mahasiswa dengan kemampuan tinggi, dapat dengan benar dan tepat menyelesaikan masalah statistika berdasarkan langkah Krulik dan Rudnick dengan bentuk representasi yang digunakan representasi verbal, representasi visual, dan representasi simbolik. Mahasiswa dengan kemampuan matematika sedang, dalam menyelesaikan masalah statistika menggunakan bantuan representasi verbal dan simbolik dengan benar namun mengalami kesulitan mengolah dan menggunakan informasi sehingga mengalami kesalahan pada langkah find and answer serta reflect andextend kurang tepat. Mahasiswa dengan kemampuan matematika rendah cenderung mengerjakan soal dengan tergesa-gesa agar cepat selesai tanpa memahami makna yang terdapat pada soal dengan jeli sehingga menyebabkan kesalahan pada semua langkah Krulik dan Rudnick, bentuk representasi yang digunakan representasi verbal dan simbolik namun kurang tepat.

\section{Saran}

Berdasarkan hasil penelitian tersebut, penulis memberikan beberapa 
saran yang dirangkum seperti berikut: (1) Berdasarkan penggunaan representasi matematis mahasiswa dalam menyelesaikan masalah statistika ternyata dihasilkan representasi yang berbeda-beda namun cenderung mengarah pada bentuk representasi tertentu. Hal ini dapat dijadikan bahan referensi untuk mengembangkan atau melakukan penelitian terkait penggunaan bentuk representasi matematis yang memiliki karakteristik yang berbeda; (2) Setelah diketahui representasi matematis yang sering digunakan oleh subjek dengan kemampuan tinggi, sedang dan rendah dalam mata kuliah statistika memberikan kemudahan bagi pengampu agar: (a) menggunakan ragam bentuk representasi (verbal, simbolik, visual) dalam melakukan pembelajaran sehingga penggunaan representasi matematis tidak selalu pada penggunaan representasi simbolik untuk mahasiswa dengan kemampuan tinggi dan sedang dan representasi verbal untuk mahasiswa dengan kemampuan rendah; (b) memberikan banyak latihan soal kepada mahasiswa yang dapat mengarahkan untuk menyelesaikannya menggunakan beragam bentuk representasi (verbal, simbolik, visual); (3) Bagi peneliti yang ingin melakukan penelitian sejenis terkait dengan representasi matematis siswa agar dapat mengembangkan penelitian ini dengan meneliti pada subjek selain mahasiswa dengan kemampuan dan materi yang berbeda.

\section{DAFTAR PUSTAKA}

Azizah, F. (2015). Analisis kemampuan pemecahan masalah matematika berdasarkan taksonomi SOLO pada sub pokok bahasan balok siswa kelas VIII-H SMP Negeri 7 Jember. Skripsi. Diakses tanggal 5Agustus 2019 dari UniversitasJember:http://repositor y.u nej.ac.id/handle/123456789/6652 $\underline{3}$

Gagatis, A and Elia, I. (2004).The Effect of Different Modes of Representation on Mathematical Problem Solving.Proceedings of the 28th Conferencee of the International Group for the Psychology of Mathematics Education, Vol 2 pp447-454.

Goldin, A. (2002). Representation in Mathematical Learning and Problem Solving. Handbook of International Research in Mathematic Education, pp:197218

Hwang, W. Y., Chen, N. S., Dung, J. J., \& Yang, Y. L. (2007).Multiple representation skills and creativity effects on mathematical problem solving using a multimedia whiteboard system. Educational Technology \& Society, 10(2), 191212

Krulik, S. and Rudnick, J.A. (1995).The New Sourcebook for Teaching Reasoning andProblem Solving in Elementary School.United States of America: Allyn \&Bacon. 
Miles, M. B. \& Huberman, M. (1992). Analisis Data Kualitatif. Jakarta: Universitas Indonesia.

Mudzakir H.S. (2006). Strategi Pembelajaran Think-Talk-Write Untuk MeningkatkanKemampuan Representasi Matematis Siswa SMP. Tesis. Tidak dipublikasikan. UPI Bandung

National Council of Teachers Mathematics.(2000). Principles and Standards of SchoolMathematics. Reston: VA.

Rezki, A (2018). Analisis Kemampuan Representasi Matematis dalam Pemecahan Masalah Geometri serta Faktor-faktor yang Mempengaruhinya.Jurnal Review Pembelajaran Matematika Volume 3, No 2 Desember 2018 ISSN $2503-1384$
Rifqiyana, L. (2015). Analisis Kemampuan Berpikir Kritis Siswa dengan Pembelajaran Model 4K Materi Geometri Kelas VIII ditinjau dari Gaya Kognitif Siswa.Skripsi, tidak dipublikasikan. Universitas Semarang

Sabirin, M. (2014). Representasi dalam Pembelajaran Matematika. JPM IAIN Antasari 1(2) hal. 33-44.

Yudhanegara, M. R.\& Leastari, K. E.(2017). Analisis Kemampuan Representasi matematis mahasiswa pada mata kuliah sistem geometri berdasarkan latar belakang prestasi belajar mata kuliah geometri transformasi. Jurnal Penelitian Pendidikan dan Pengajaran Matematika Vol. 3 no. 2, pp. 83-88, September 2017ISSN: 2460-8599 